\title{
Comparative study of the polyphenol content-related anti-inflammatory and antioxidant activities of two Urera aurantiaca specimens from different geographical areas
}

\author{
Carla Marrassini* ${ }^{*}$, Ignacio Peralta and Claudia Anesini
}

\begin{abstract}
Background: Urera aurantiaca is an Argentinean species that has been traditionally used to treat symptoms of inflammation. The aim of this study was to determine and compare the anti-inflammatory and antioxidant effects of two specimens of Urera aurantiaca obtained in the provinces of Salta and Misiones, which are two different geographical areas of Argentina.

Methods: The anti-inflammatory activity of the extracts was tested in LPS-stimulated macrophages through the DPPH radical scavenging activity, the SOD-like activity, the reducing power and the inhibition of lipid peroxidation. The anti-inflammatory activity was also evaluated by the inhibition of albumin denaturation and proteinase inhibitory action tests. The total polyphenols, flavonoids and tannins content were quantified.

Results: Both extracts were able to reduce the augmented NO release in LPS-activated macrophages and showed antioxidant and in vitro anti-inflammatory activities. The polyphenols content was higher in the extract obtained from the specimen from Salta than in that obtained in Misiones. This finding accounts for the higher anti-inflammatory and antioxidant properties obtained with the former.
\end{abstract}

Conclusion: The differences in chemical composition and the biological activities observed between the extracts are probably related to the different environmental conditions found in both provinces.

Keywords: Urera aurantiaca, Inflammation, Antioxidant activity, Macrophages, Polyphenols

\section{Background}

Inflammation is a defence mechanism against tissue damage caused by either mechanical, chemical, or microbial stimuli. The main cells involved in the inflammatory response are monocytes/macrophages, polymorphonuclear leucocytes, and endothelial cells. When these cells become activated, they aggregate and infiltrate tissues where the respiratory burst is triggered

\footnotetext{
*Correspondence: cmarra@ffyb.uba.ar
}

Facultad de Farmacia y Bioquímica, Instituto de la Química y Metabolismo del Fármaco (IQUIMEFA), Consejo Nacional de Investigaciones Científicas y Técnicas, Universidad de Buenos Aires, Buenos Aires, Argentina to increase the oxygen consumption and the production of cytokines and reactive oxygen species (ROS), as well as other inflammation mediators [1]. The ROS that are produced during the inflammatory response facilitating it; however, when produced for prolonged periods, these mediators can promote oxidative stress and chronic inflammation-associated disorders. It is known that inflammation and oxidative stress are interrelated processes [2].

In living organisms, the energy production is achieved through oxidation processes. Thus, the aerobic metabolism entails the generation of different ROS, such as singlet oxygen, superoxide, peroxyl and hydroxyl 
radicals, and reactive nitrogen species (RNS), including peroxynitrite and nitric oxide (NO). Apart from their physiological activity, ROS and RNS oxidise membrane lipids, proteins and DNA, leading to diseases, such as cancer, cardiovascular diseases, cataracts, asthma, hepatitis, liver injury and immunodeficiency diseases [3].

During inflammation, ROS and RNS are largely produced by macrophages, which play a central role in both innate and adaptive immunity. Macrophages are known to perform several functions such as killing foreign organisms, presenting antigens, phagocytising foreign invaders, and producing chemical mediators, such as cytokines and those of oxidative stress. These cells interact with $\mathrm{T}$ and $\mathrm{B}$ cells, natural killer and dendritic cells, neutrophils, and fibroblasts.

The lipopolysaccharide (LPS), which is a component of cell walls and the major virulence factor of Gram-negative bacteria, can induce oxidative stress in macrophages [4].

Nowadays, there is an increasing interest in the use of plant antioxidants for dietary, pharmaceutical and cosmetic purposes. This is mainly due to their strong biological activity, exceeding those of many carcinogenic synthetic antioxidants. Many plants contain antioxidant compounds and these compounds protect cells against the damaging effects of ROS. Epidemiological studies have indicated the beneficial effects of plant antioxidants in patients with chronic diseases [5]. Thus, the antioxidant activity of plant-derived compounds is currently being studied, as regards the free radical quenching ability, mainly of polyphenol compounds.

Urera aurantiaca Wedd. (Urticaceae), commonly known as "ortiga colorada", "pino guasú", and "pica pica", is an Argentinean native herb also growing in Paraguay, Uruguay, Bolivia, and Brazil. $U$. aurantiaca is used in folk medicine to treat rheumatic pain, varicose veins, furuncles, bruises, inflammation, tooth pain, dermal diseases, and trauma [6].

In a previous work, the in vivo anti-inflammatory and antinociceptive effects of a methanolic extract of $U$. aurantiaca from Paraguay have been reported [7]. Its modulatory effect on immune and tumoral cells during inflammation has also been demonstrated [8].

Species of the Urticaceae family have been used in traditional Chinese medicine. For example, Laportea bulbifera (Siebold \& Zucc.) Wedd. (Urticaceae) is used for the treatment and management of urinary stones [9]; Gonostegia hirta (Blume) Miq. (Urticaceae) is used to treat many types of injuries [10]; Pilea microphylla (L.) Liebm. (Urticaceae) is used for the treatment of osteoarthritis [11]; Pellionia repens (Lour.) Merr. (Urticaceae) is used for the treatment of skin injuries [12]; Boehmeria nivea (L.) Gaudich. (Urticaceae) is employed as a pro-coagulant, to reduce swelling and as detoxifying [13].
Urera aurantiaca is distributed in different phytogeographic zones in Argentina. It is known that specimens of the same species growing under different environmental conditions differ in the production levels of primary and secondary metabolites. This phenomenon is due to the different metabolic requirements to accomplish long term acclimation or local adaptation, seasonal differences related to phenology or environmental changes of both biotic and abiotic factors, geographical differences involving different populations (genetic differences within a plant species), etc. $[14,15]$.

Considering the popular medicinal use of $U$. aurantiaca and the biological activities previously reported for this species, the objectives of this work were to analyse and compare the antioxidant effect of two species of $U$. aurantiaca obtained in the provinces of Salta and Misiones, which are two different geographical areas of Argentina. The free radicals scavenging capacity, the reducing power, the SOD-like activity, and the ability to diminish the production of NO in lipopolysaccharide (LPS)-stimulated macrophages were studied. The in vitro anti-inflammatory activity in relation to ROS generation was also studied. Finally, polyphenols such as flavonoids and tannins were quantified to relate their presence with the activities mentioned.

\section{Methods}

The minimum standards of reporting checklist contains details of the experimental design, and resources used in this study (Additional file 1).

\section{Plant material}

Urera aurantiaca Wedd. (Urticaceae) obtained in the province of Salta was collected in Orán, Salta, Argentina $\left(23^{\circ} 07^{\prime} 01.0^{\prime \prime} \mathrm{S}, \quad 64^{\circ} 18^{\prime} 40.2^{\prime \prime} \mathrm{W}\right)$ in April 2013 by P. Mercado. A voucher specimen (no. 212) was deposited at Herbario LIL Fundación Miguel Lillo, San Miguel de Tucumán, Argentina.

Urera aurantiaca Wedd. (Urticaceae) obtained in the province of Misiones province was collected in Eldorado, Misiones, Argentina $\left(26^{\circ} 24^{\prime} 23.4^{\prime \prime} \mathrm{S}, 54^{\circ} 41^{\prime} 37.3^{\prime \prime} \mathrm{W}\right)$ in April 2013 by H.A. Keller. A voucher specimen (no. 11330) was deposited at Herbario del Instituto de Botánica del Nordeste (CTES), Corrientes, Argentina.

\section{Extraction}

The dried aerial parts of the specimens obtained Salta and Misiones were ground to a fine powder and extracted sequentially by maceration with solvents of different polarity. Briefly, the plant powder was first extracted with dichloromethane, then with ethyl acetate, and finally, the marc was extracted with methanol. Solvents were put in contact with the plant material overnight in 
order to obtain an extract enriched in polyphenols. After extraction, the methanol extracts were lyophilised. Yields were $4.4 \%$ for the Salta extract and $4.6 \%$ for the Misiones extract.

\section{Phytochemical analysis Total phenol content}

The total phenol content in the extracts was determined by the Folin-Ciocalteu's colorimetric method, as described by Singleton et al. [16]. The absorbance was measured at $760 \mathrm{~nm}$ and compared with a gallic acid calibration curve. Results were expressed as mg of gallic acid equivalents per gram of extract (GAE/g).

\section{Flavonoids determination}

The total flavonoids content was determined in the extracts by the aluminum chloride colorimetric method, as described by Chang et al. [17]. Briefly, the diluted standard solutions or the extract $(0.5 \mathrm{ml})$ were mixed with $1.5 \mathrm{ml} 95 \%$ ethanol, $0.1 \mathrm{ml} 10 \%$ aluminum chloride, $0.1 \mathrm{ml} 1 \mathrm{M}$ potassium acetate and $2.8 \mathrm{ml}$ distilled water. After incubation at room temperature for $30 \mathrm{~min}$, the absorbance was measured at $415 \mathrm{~nm}$. Dilutions of quercetin in ethanol were used to generate the calibration curve $(125,250,500$ and $1000 \mu \mathrm{g} / \mathrm{ml})$.

\section{Tannins determination}

The tannin content was calculated as the difference between the contents of total phenols and the noncomplex residual phenols [18] after the removal of tannins from the medium by complexation with casein, as described by Amorim et al. [19] with slight modifications. Briefly, $500 \mathrm{mg}$ of casein were transferred into a $25 \mathrm{ml}$ Erlenmeyer flask. Five $\mathrm{ml}$ of the extract and $5 \mathrm{ml}$ of distilled water were then added. After $2 \mathrm{~h}$, which is the time period required for the complexing of the tannins to the protein, the extract was filtered into a $10 \mathrm{ml}$ volumetric flask and the volume was then adjusted to $10 \mathrm{ml}$ with distilled water. The tannin content was expressed as the percentage of the total phenols that were complexed with casein.

\section{High performance liquid chromatography}

The HPLC method was developed and validated according to Filip et al. [20] and performed in a Varian 9000 instrument equipped with a diode array detector and a Rheodyne injector fitted with a $20 \mu \mathrm{l}$ loop. A C18 column (Kinetex $5 \mu \mathrm{m}, 150 \mathrm{~mm} \times 4.6 \mathrm{~mm}$ ) was employed. As mobile phase, solvent A: $\mathrm{H}_{2} \mathrm{O} / \mathrm{AcOH}(98: 2)$ and solvent $\mathrm{B}: \mathrm{MeOH} / \mathrm{AcOH}$ (98:2) were used. The elution gradient was: from 15 to $40 \% \mathrm{~B}$ in $30 \mathrm{~min}$; from 40 to $75 \%$ $\mathrm{B}$ in $10 \mathrm{~min}$; from 75 to $85 \% \mathrm{~B}$ in $5 \mathrm{~min}$. The elution was performed at flow rate of $1.2 \mathrm{ml} / \mathrm{min}$. Detection was done at $325 \mathrm{~nm}$.

\section{Cell suspensions and culture conditions}

The American Type Culture Collection (ATCC) RAW264.7 murine macrophage cell line was cultured in corlorless Dulbecco's Modified Eagle's medium supplemented with $10 \%$ FBS, $2 \mathrm{mM}$ glutamine and $100 \mathrm{IU} / \mathrm{ml}$ penicillin and $100 \mu \mathrm{g} / \mathrm{ml}$ streptomycin and kept in a humidified incubator at $5 \% \mathrm{CO}_{2}$ and $37^{\circ} \mathrm{C}$.

\section{Cell proliferation and nitric oxide determination}

To determine cell proliferation rate and NO production, macrophages were incubated for $24 \mathrm{~h}$ without any treatment (basal conditions) or with LPS $(1 \mu \mathrm{g} / \mathrm{ml})$ alone or in the presence of different concentrations of the extracts. After incubation, the supernatant was separated to determine the NO levels and the cells were used to determine proliferation. The nitrite accumulated in the culture medium, which is an indicator of $\mathrm{NO}$ production, was measured by the Griess' reaction [21]. Briefly, $100 \mu \mathrm{l}$ of each supernatant were mixed with $50 \mu \mathrm{l}$ of a $1 \%$ sulfanilamide solution in $5 \%$ phosphoric acid and $50 \mu \mathrm{l}$ of a $0.1 \%$ naphthylene diamine dihydrochloride solution. The mixture was incubated at room temperature for $20 \mathrm{~min}$, and the absorbance was read at $540 \mathrm{~nm}$. As standard curve, serial dilutions of a $\mathrm{NaNO}_{2}$ solution were employed.

Results were expressed as mean $\pm S E M$ of three determinations performed in triplicate.

Cell proliferation was determined by the reduction of 3-(4,5-dimethylthiazol-2-yl)-2,5-diphenyltetrazolium bromide (MTT) (Sigma). Briefly, cells were incubated for $4 \mathrm{~h}$ in $100 \mu \mathrm{l}$ RPMI 1640 and $10 \mu \mathrm{l}$ of $5 \mathrm{mg} / \mathrm{ml} \mathrm{MTT}$ (Sigma, St. Louis, MO, USA). After incubation, the formazan formed was dissolved in acidified isopropanol $(0.04 \mathrm{~N} \mathrm{HCl}$ in isopropanol) and read at $540 \mathrm{~nm}$.

\section{2,2-Diphenyl-1-picrylhydrazyl (DPPH) radical scavenging activity}

The scavenging activity of the extracts on the stable free radical DPPH was assayed by the modified method described by Blois [22]. The bleaching rate of DPPH is monitored at a characteristic wavelength in the presence of the sample. Briefly, a volume of $0.1 \mathrm{ml}$ of an aqueous dilution of the extract was mixed with $0.5 \mathrm{ml}$ of a $500 \mu \mathrm{M}$ DPPH solution in absolute ethanol and $0.4 \mathrm{ml}$ of a $0.1 \mathrm{M}$ Tris- $\mathrm{HCl}$ buffer, $\mathrm{pH}$ 7.4. The mixture was kept for $20 \mathrm{~min}$ in the darkness, and then the absorbance was read at $517 \mathrm{~nm}$. The percentage of decrease of DPPH absorbance was calculated by measuring the absorbance of the sample and applying the following equation:

$$
\% \text { of inhibition }=[1-(\text { As } / A 0)] \times 100,
$$


where As is absorbance of sample and A0 is the absorbance of the DPPH solution.

\section{Superoxide dismutase (SOD)-like activity}

To determine the SOD activity, the inhibitory capacity of the extracts on the adrenaline autoxidation was evaluated. Briefly, $50 \mu \mathrm{l}$ of the extract were treated with $910 \mu \mathrm{l}$ of sodium phosphate buffer $(0.05 \mathrm{M}) \mathrm{pH}$ : 10.7 and $1 \mathrm{mM}$ adrenaline. Under these conditions, adrenaline rapidly undergoes autoxidation to produce the adrenochrome, which is a pink coloured product that can be measured at $480 \mathrm{~nm}$ using a UV/visible spectrophotometer in kinetic mode. The antioxidant activity of sample was evaluated as the \% of epinephrine autoxidation inhibition. The absorbance was monitored at $480 \mathrm{~nm}$, and the $\Delta$ absorbance/min was determined to calculate the \% of inhibition as: [(Abs/min control - Abs/ min sample)/Abs/min control] $\times 100$ [23].

\section{Reducing power assay}

The reducing power was determined according to Ferreira et al. [24], with slight modifications. Different concentrations of the extract $(2.5 \mathrm{ml})$ were mixed with $2.5 \mathrm{ml}$ of $200 \mathrm{mM}$ sodium phosphate buffer ( $\mathrm{pH} \mathrm{6.6)}$ and $2.5 \mathrm{ml}$ of $1 \%$ potassium ferricyanide. The mixture was incubated at $50{ }^{\circ} \mathrm{C}$ for $20 \mathrm{~min}$. After adding $2.5 \mathrm{ml}$ of $10 \%$ trichloroacetic acid $(\mathrm{w} / \mathrm{v})$, the mixture was centrifuged at $3500 \mathrm{rpm}$ for $10 \mathrm{~min}$. The upper layer $(2.5 \mathrm{ml})$ was mixed with $2.5 \mathrm{ml}$ deionised water and $1 \mathrm{ml}$ of $0.1 \%$ ferric chloride, and the absorbance was measured at $700 \mathrm{~nm}$. The reducing power is directly proportional to the mixture absorbance.

\section{Inhibition of lipid peroxidation of egg yolk}

The lipid peroxidation assay was done according to Dissanayake et al. [25], with minor modifications. The egg yolk was separated from the albumen and the yolk membrane was removed. A $10 \% \mathrm{v} / \mathrm{v}$ yolk solution was prepared in $1.15 \%$ of $\mathrm{KCl}$. The solution was homogenized for $30 \mathrm{~s}$ and ultra sonicated for $5 \mathrm{~min}$.

A $1 \%(w / v)$ of thiobarbituric acid solution was then prepared in $1.1 \%(\mathrm{w} / \mathrm{v})$ SDS.

The reaction mixture contained $25 \mu \mathrm{l}$ of the extract, $125 \mu \mathrm{l}$ of egg yolk solution and $100 \mu \mathrm{l}$ of distilled water. Distilled water $(125 \mu \mathrm{l})$ was used as the control. Acetic acid $(20 \%, 375 \mu \mathrm{l})$ and $1 \%$ thiobarbituric acid $(375 \mu \mathrm{l})$ were then added. These mixtures were vortexed for $5 \mathrm{~s}$ and kept in a water bath $95{ }^{\circ} \mathrm{C}$ for $60 \mathrm{~min}$. Butanol $(1.25 \mathrm{ml})$ was added to each tube and vortexed for $5 \mathrm{~s}$. After centrifuging at $3000 \mathrm{~g}$ for $10 \mathrm{~min}$, the butanol layer was separated. Absorbance values were measured at $532 \mathrm{~nm}$.

\section{Inhibition of albumin denaturation}

The method was performed according to Kumari et al. [26] and Sakat et al. [27], with minor modifications. The reaction mixture $(0.5 \mathrm{ml})$ consisted of $0.40 \mathrm{ml}$ bovine serum albumin (1\% aqueous solution), $0.05 \mathrm{ml}$ of the extract at different concentrations (1000, 800,600 , and $400 \mu \mathrm{g} / \mathrm{ml}$ ), and $0.05 \mathrm{ml}$ of salicylic acid (inductor of protein denaturation). As positive control, distilled water $(0.05 \mathrm{ml})$ was used instead of the extracts while as negative control, no salicylic acid was employed. Samples were incubated at $37{ }^{\circ} \mathrm{C}$ for $20 \mathrm{~min}$ and then heated at $57{ }^{\circ} \mathrm{C}$ for $20 \mathrm{~min}$. After cooling the samples, $2.5 \mathrm{ml}$ phosphate buffer saline $(\mathrm{pH}$ 6.3) were added to each tube. Turbidity was measured spectrophotometrically at $660 \mathrm{~nm}$. The percentage inhibition of protein denaturation was calculated as follows:

$$
\text { Percent inhibition }=\frac{\mathrm{Abs}_{\text {control }}-\mathrm{Abs}_{\text {treated }}}{\mathrm{Abs}_{\text {Control }}} \times 100
$$

where $\mathrm{Abs}_{\text {control }}$ represents $100 \%$ protein denaturation.

\section{Proteinase inhibitory action}

The antitryptic activity of the extract was assayed as described by Oyedapo and Famurewa [28], with minor modifications. The reaction mixture $(1.0 \mathrm{ml})$ contained $0.03 \mathrm{ml}$ trypsin $(0.3 \mu \mathrm{g}), 0.5 \mathrm{ml}$ of the extract at different concentrations $(10,25,50$, and $100 \mu \mathrm{g} / \mathrm{ml})$ and $0.5 \mathrm{ml}$ of $20 \mathrm{mM}$ Tris- $\mathrm{HCl}$ buffer (pH 7.4). The mixture was incubated at $37{ }^{\circ} \mathrm{C}$ for $5 \mathrm{~min}$ and then, $0.5 \mathrm{ml}$ of $0.8 \%$ $(\mathrm{w} / \mathrm{v})$ casein was added. The mixture was further incubated for $20 \mathrm{~min}$ and $1 \mathrm{ml}$ of $70 \%$ perchloric acid was added to terminate the reaction. The cloudy suspension was clarified by centrifugation and the absorbance of the supernatant was read at $280 \mathrm{~nm}$ against buffer as blank.

\section{Statistical analysis}

Data were expressed as the average of triplicate values of three independent experiments. To compare two values, the Student's $t$ test was used. Multiple comparisons were performed by analysis of variance (ANOVA) and the Dunnett's test. A $\mathrm{p}<0.05$ was considered statistically significant.

\section{Results}

Firstly, the extracts were obtained and their chemical composition was determined. The objective of the extraction was to obtain polyphenolic compounds. Once the extracts were prepared, the total polyphenols, flavonoids, and tannins were quantified. Table 1 shows that the Salta extract rendered the highest total phenolic and flavonoids content, meanwhile the Misiones extract presented a higher amount of tannins than the Salta 
Table 1 Quantitative determination of polyphenols, flavonoids, and tannins in Salta and Misiones extracts

\begin{tabular}{llll}
\hline Urera aurantiaca extracts & Total polyphenols (GAE/g) & Flavonoids (\%) & Tannins (\%) \\
\hline Salta & $30.90 \pm 1.8^{\mathrm{a}}$ & $2.10 \pm 0.015^{\mathrm{a}}$ & $39.7 \pm 0.2^{\mathrm{a}}$ \\
Misiones & $14.05 \pm 2.60^{\mathrm{b}}$ & $1.49 \pm 0.052^{\mathrm{b}}$ & $48.2 \pm 1.1^{\mathrm{b}}$
\end{tabular}

Statistical differences were determined by $t$-Student test $(\mathrm{a} \neq \mathrm{b}: \mathrm{p}<0.05)$

extract. Furthermore, a chromatographic profile was also obtained by HPLC analysis. Figure 1 shows that the differences in the extracts appeared to be quantitative and not qualitative.

Secondly, the antioxidant activity of the extracts was measured with the DPPH test. Both extracts presented a polyphenol concentration-dependent antioxidant activity (Fig. 2a). The $\mathrm{EC}_{50}$ obtained with the Salta extract was fourfold lower than that of Misiones extract (Fig. 2b-d).

Furthermore, the reducing power of the extracts was studied. A concentration-dependent reducing power was demonstrated in both extracts (Fig. 3a). However, the Salta extract reached an inhibition of $100 \%$ at $1000 \mu \mathrm{g} / \mathrm{ml}$, meanwhile for the Misiones extract, the maximum inhibition achieved was $33.7 \%$ at the same concentration. In addition, the Salta extract presented a lower $\mathrm{EC}_{50}$ value. In Fig. $3 \mathrm{~b}-\mathrm{d}$ the $\mathrm{EC}_{50}$ values for this activity in comparison with the polyphenols, flavonoids and tannins content is shown.

The SOD-like activity was then used as a more specific method for the measurement of the antioxidant activity. Both extracts presented a concentration-dependent SOD-like activity; however, the $\mathrm{EC}_{50}$ for the Misiones extract was lower than that exhibited by the Salta extract (363 vs. $537 \mu \mathrm{g} / \mathrm{ml}$, Fig. 4a). In Fig. 4b-d the $\mathrm{EC}_{50}$ values for this activity in comparison with the polyphenols, flavonoids and tannins content is shown.

To complete the antioxidant activity profile, the inhibition of lipid peroxidation of egg yolk was assayed. Results indicated that the Salta extract exerted an inhibitory
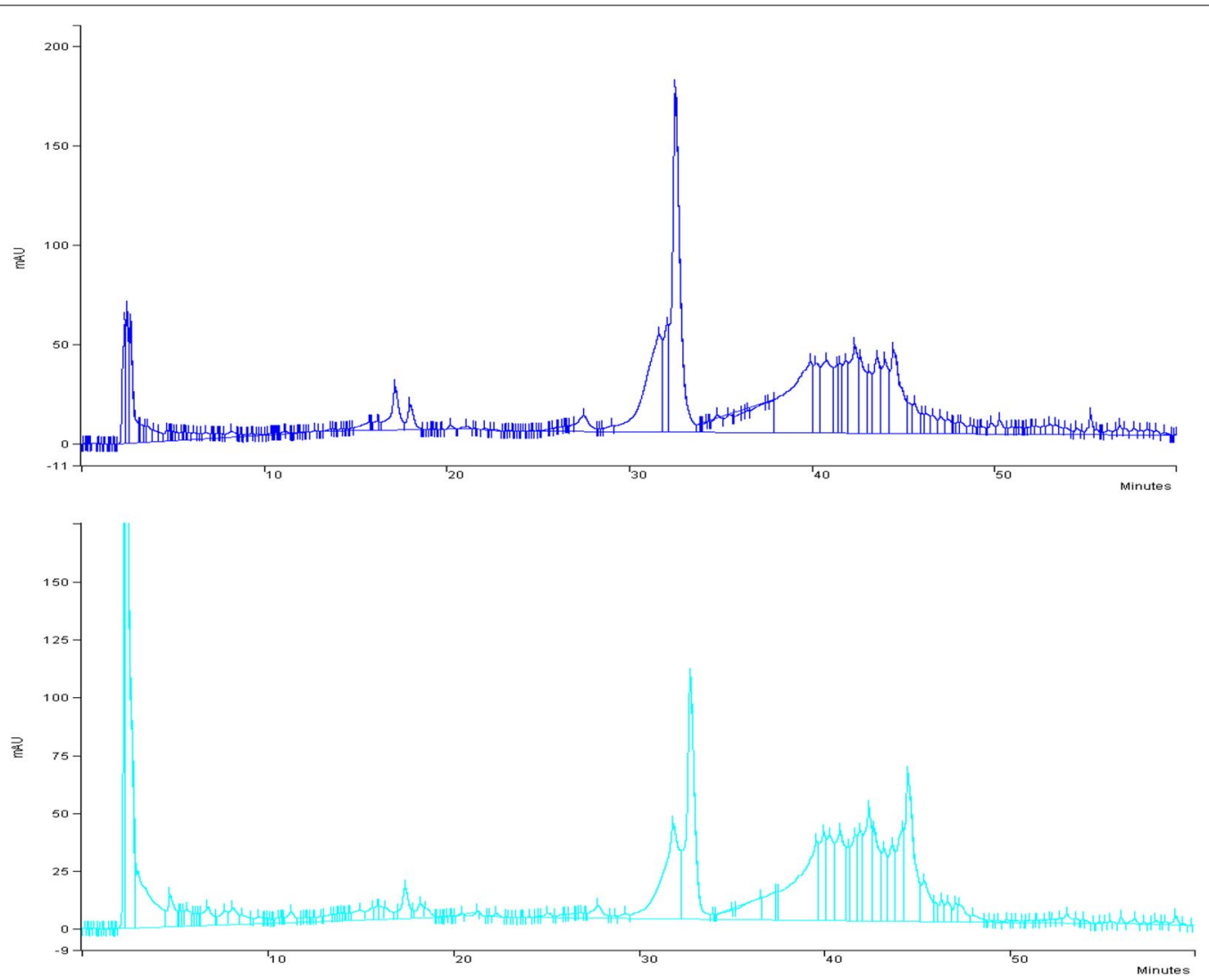

Fig. 1 HPLC profiles: a Salta extract, b Misiones extract 

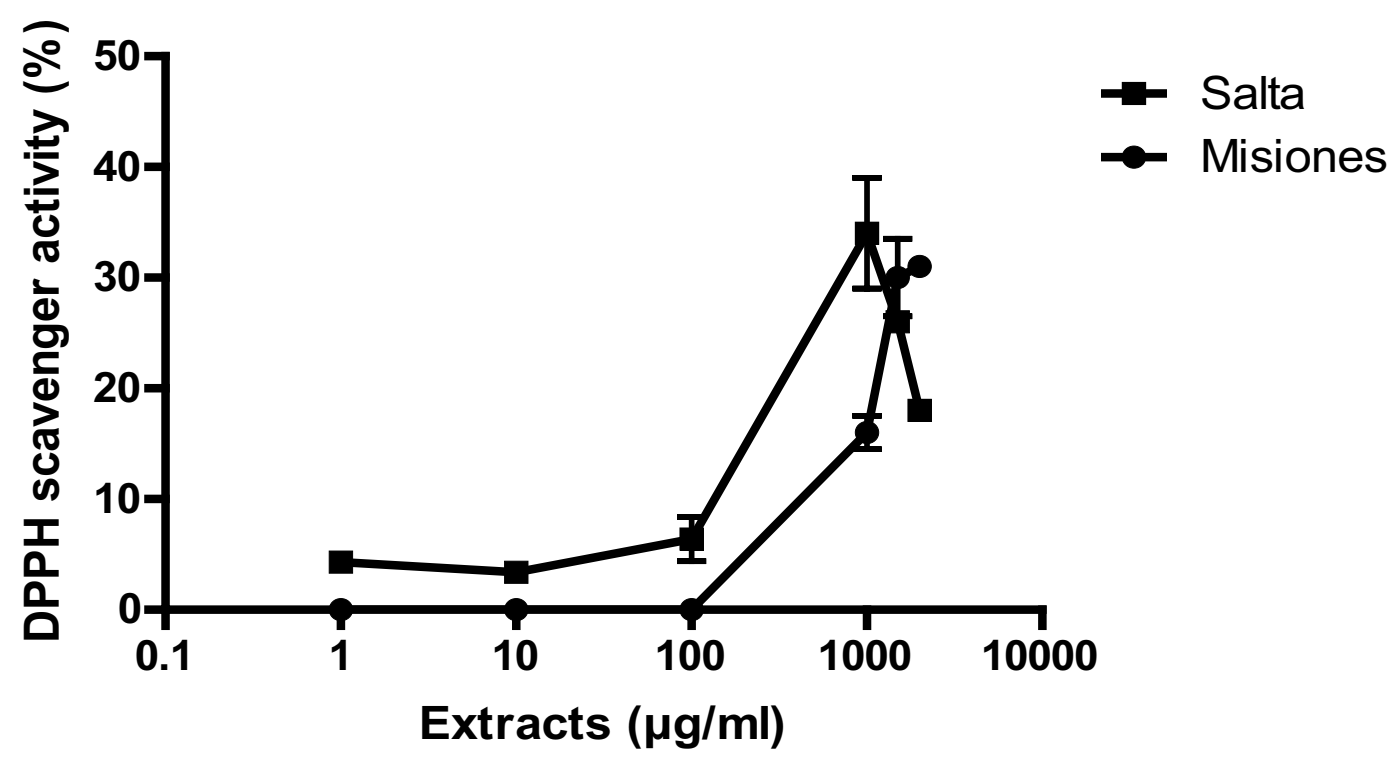

\section{Extracts}

\section{DPPH scavenger activity EC50 ( $\mathrm{gg} / \mathrm{ml})$}

\section{Misiones}

Salta

\section{$977 \pm 40$}

Fig. 2 DPPH scavenger activity. a DPPH antioxidant activity as a function of the extract concentration. $\mathbf{b}-\mathbf{d}$ Comparison between the DPPH activity and the polyphenols, flavonoids and tannins content and $\mathrm{EC}_{50}$ for Salta and Misiones extracts. Results represent mean $\pm \mathrm{SEM}$ of three experiments performed in triplicate. ${ }^{* * *} \mathrm{p}<0.001$ significant differences between extracts $\mathrm{EC}_{50}$

effect that was higher than that of the Misiones extract, exhibiting a lower $\mathrm{EC}_{50}$ value $(1862 \mu \mathrm{g} / \mathrm{ml})$ and a maximum effect of $52 \%$ of inhibition at $2 \mathrm{mg} / \mathrm{ml}$. On the other hand, the Misiones extract also inhibited lipid peroxidation ( $\mathrm{EC}_{50}$ : $>2000$; maximum inhibition: 16.7\%, Fig. 5a). It noteworthy that the Misiones extract, at $100 \mu \mathrm{g} / \mathrm{ml}$, exerted a pro-oxidant action, while the Salta extract, at $100 \mu \mathrm{g} / \mathrm{ml}$, caused an inhibition of lipid peroxidation of $12 \%$. Figure $5 \mathrm{~b}-\mathrm{d}$ show the $\mathrm{EC}_{50}$ value for this activity in comparison with the polyphenols, flavonoids and tannins content.

The in vitro anti-inflammatory activity was studied in relation with the antioxidant activity by two methods: the inhibition of albumin denaturation and the proteinase inhibitory action. As shown in Fig. 6a, both extracts inhibited the heat-induced albumin denaturation; however, the Salta extract presented a maximum inhibition of
$64.4 \%$ at $1000 \mu \mathrm{g} / \mathrm{ml}$, as compared to the Misiones extract with which the maximum inhibition achieved was $11.2 \%$, at the same concentration. In addition, the Salta extract exhibited a lower $\mathrm{EC}_{50}$. In Fig. $6 \mathrm{~b}-\mathrm{d}$, the $\mathrm{EC}_{50}$ values are shown in comparison with each compound content.

Finally, the trypsin inhibitory capacity was higher for the Salta extract than for the Misiones extract, showing a lower $\mathrm{EC}_{50}$ value (Fig. 7a). In Fig. $7 \mathrm{~b}-\mathrm{d}$, the relationship between this activity and the compounds content is shown.

Finally, the effect on the nitrosative stress was studied on macrophages stimulated or not with LPS, which is an inductor of NO. The percentage of NO produced and the effect on cell proliferation were studied.

Figure $8 \mathrm{a}$ shows that in unstimulated macrophages, low concentrations of the Salta extract decreased the NO production, while higher concentrations increased 


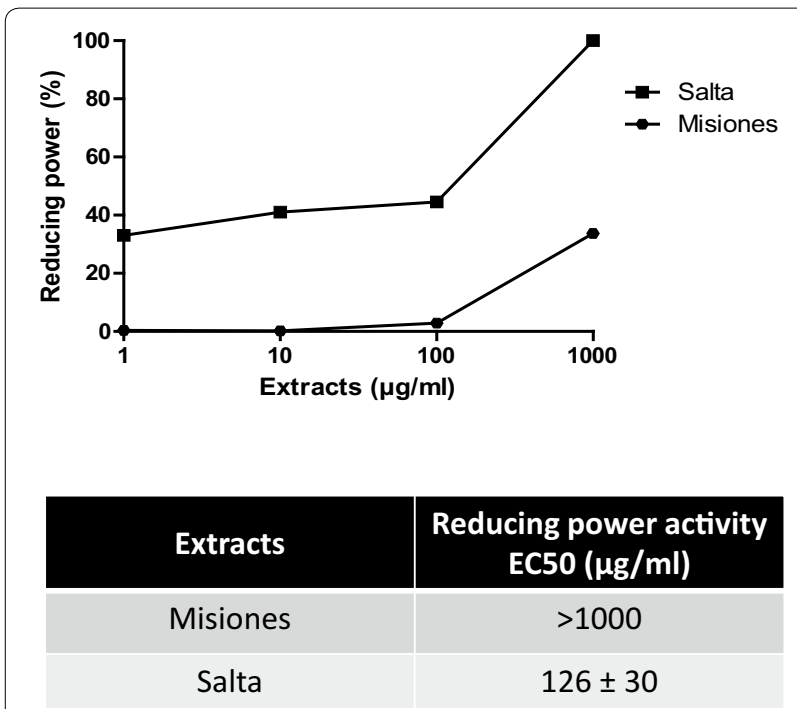

Fig. 3 Reducing power determination. a Reducing power as a function of the extract concentration. b-d Comparison between the reducing power and the polyphenols, flavonoids and tannins content and $\mathrm{EC}_{50}$ for Salta and Misiones extracts. Results represent mean $\pm S E M$ of three experiments performed in triplicate. Significant differences between extracts $\mathrm{EC}_{50}$ values were determined by the $t$-Student test $\left({ }^{* *} p<0.001\right)$

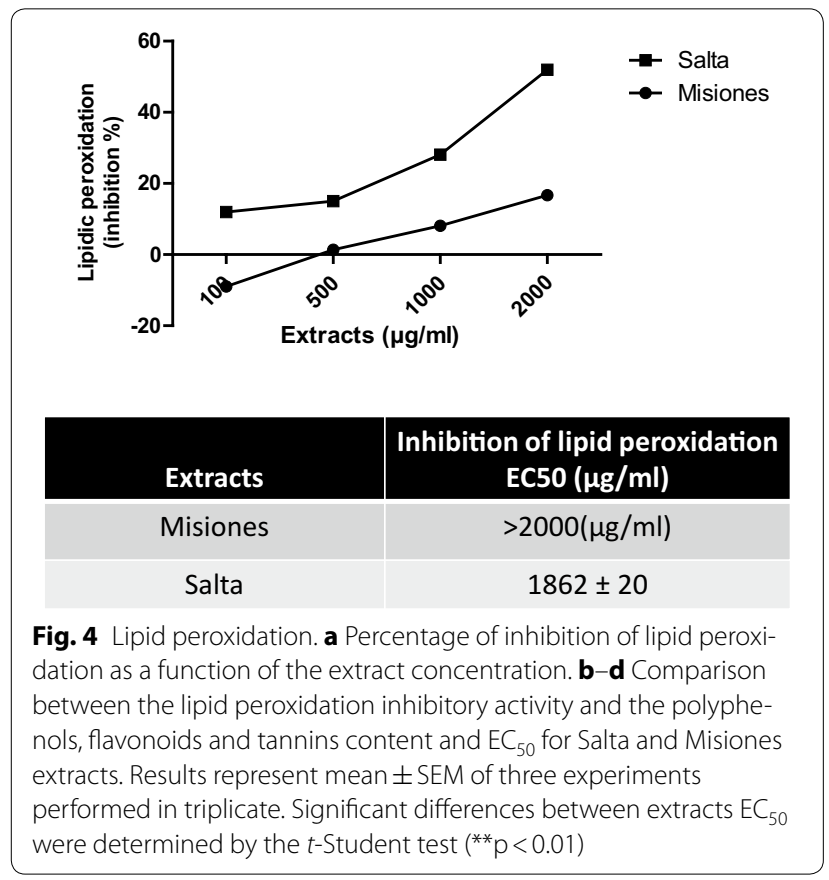

the production of this mediator. On the other hand, the Misiones extract increased the NO production at all the concentrations assayed. LPS increased the NO release by macrophages (data not shown). Neither the Salta nor the Misiones extract modified cell proliferation at any

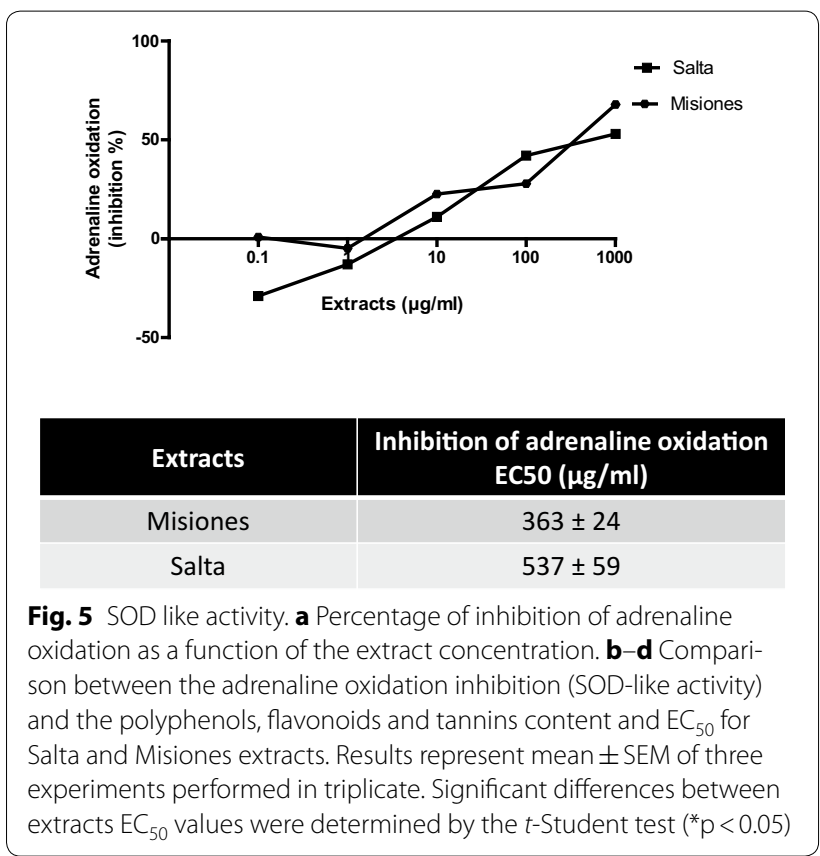

concentration, but LPS was capable of decreasing cells proliferation. Under LPS stimulation, the Salta and Misiones extracts presented a biphasic effect, increasing the NO production at low concentrations and decreasing it at higher ones. The effect exerted by the Salta extract at high concentrations was higher than that of the Misiones extract (Fig. 8b). Moreover, the Salta extract, at $100 \mu \mathrm{g} /$ $\mathrm{ml}$, and the Misiones extract, at 100 and at $250 \mu \mathrm{g} / \mathrm{ml}$ were capable of reversing the antiproliferative effect exerted by LPS.

\section{Discussion}

In this work the polyphenol-related antioxidant activity of two extracts of Urera aurantiaca from different geographical zones form Argentina was demonstrated.

DPPH.is a stable free radical with a maximum absorbance at $517 \mathrm{~nm}$. This free radical can readily be scavenged by an antioxidant to be transformed into 1,1-diphenyl-2-picrylhydrazine. The degree of bleaching indicates the scavenging power of the extract. In this assay, the Salta extract presented higher scavenging activity and potency than the Misiones extract.

The extracts also proved to have reducing power. This effect was assessed by direct electron donation in the reduction of $\left[\mathrm{Fe}(\mathrm{CN})_{6}\right]^{3-}$ to $\left[\mathrm{Fe}(\mathrm{CN})_{6}\right]^{4-}[29]$. The product was visualized by the appearance of the intense Prussian blue coloured complex, whose absorbance was measured at $700 \mathrm{~nm}$. The Salta extract had a higher capacity (lower $\mathrm{EC}_{50}$ ) than the Misiones extract in reducing the complex $\mathrm{Fe}^{3+} /$ ferricyanide, reaching 


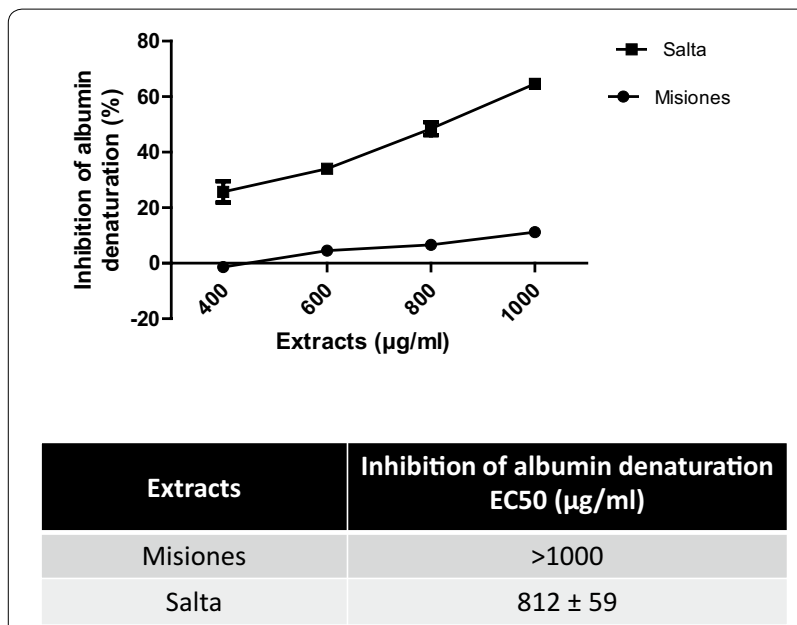

Fig. 6 Inhibition of albumin denaturation. a Percentage of inhibition of albumin denaturation as a function of the extract concentration. b-d Comparison between the albumin denaturation inhibitory action and the polyphenols, flavonoids and tannins content and $\mathrm{EC}_{50}$ for Salta and Misiones extracts. Results represent mean \pm SEM of three experiments performed in triplicate. Significant differences between extracts $\mathrm{EC}_{50}$ values were determined by the $t$-Student test $\left({ }^{*} p<0.05\right)$
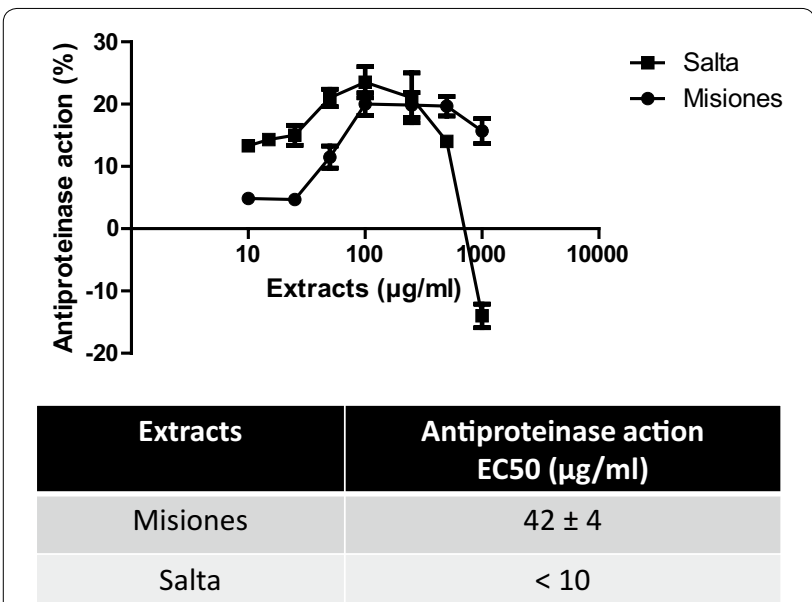

Fig. 7 Proteinase inhibitory action. a Percentage of trypsin inhibition as a function of the extract concentration. b-d Comparison between the proteinase inhibitory action and the polyphenols, flavonoids and tannins content and $\mathrm{EC}_{50}$ for Salta and Misiones. Results represent mean \pm SEM of three experiments performed in triplicate. Significant differences between extracts $\mathrm{EC}_{50}$ were determined by the $t$-Student test $\left.{ }^{* *} p<0.01\right)$

the highest inhibitory activity. The antioxidant effect exerted by reductants is based on the interruption of free radical chain reaction by donation of a hydrogen atom. Reductants also react with certain precursors of peroxide, thus preventing peroxide formation and lipid peroxidation. Our results indicate that the marked reducing power and DPPH scavenger activities exerted by the Salta extract seem to be due to the presence of polyphenols, such as flavonoids, whose content was directly proportional to such biological activity. The reducing power of these compounds is achieved through electron donation to free radicals to convert them into more stable products thus terminating the free radical chain reaction. The scavenging activity and the reducing power are known to be related to the nature of the phenolic compounds, which contribute to their electron transfer/hydrogen donating ability [30]. Thus, flavonoids generally have higher antioxidant activity because of the double bonds present in ring $\mathrm{C}$, and their antioxidant ability depends on their hydroxyl group arrangement [31]. On the contrary, tannins did not appear not to be related to these effects since the Salta extract presented a higher potency than the Misiones extract and a lower tannins content.

The Salta extract showed scavenger activity and reducing power that were directly proportional to the inhibition on lipid peroxidation. Moreover, the inhibition of lipid peroxidation correlated positively with the presence of flavonoids and not with the presence of tannins. The inhibition of lipid peroxidation might be due to the hydrogen-donating capacity of phenolic derivatives and subsequent radical stabilization.

On the other hand, the SOD-like activity was higher in the Misiones extract, and such activity correlated with a higher tannin content, as compared to the Salta extract. The SOD-like activity exerted by the extract is highly desirable, since such activity would contribute to the elimination of the superoxide radical, which causes tissue injury, including carcinogenesis, inflammation, and aging. Many clinical trials have been carried out to assess the efficacy of SOD to treat several diseases caused by the generation of high levels of superoxide. However, the treatment must be administered by the parenteral route, since SOD is inactivated by digestive enzymes and gastric juices. An alternative approach is to find low molecular weight compounds that mimic SOD or which can enhance its enzymatic activity. Such mimicry was achieved by the Misiones extract.

It is known that oxidative stress induces inflammation and vice versa. In this regard, the denaturation of proteins is a well-documented cause of inflammation, and ROS are known to stimulate this process. Salicylic acid has been demonstrated to have a dose-dependent ability to induce thermal protein denaturation by ROS generation. Proteolytic enzymes, such as trypsin, which are essential modulators of the inflammatory response [32], are also activated by ROS. To complete the study of antioxidant activity, the effect of the extracts was assayed on albumin denaturation and on tryptic casein hydrolysis. As 


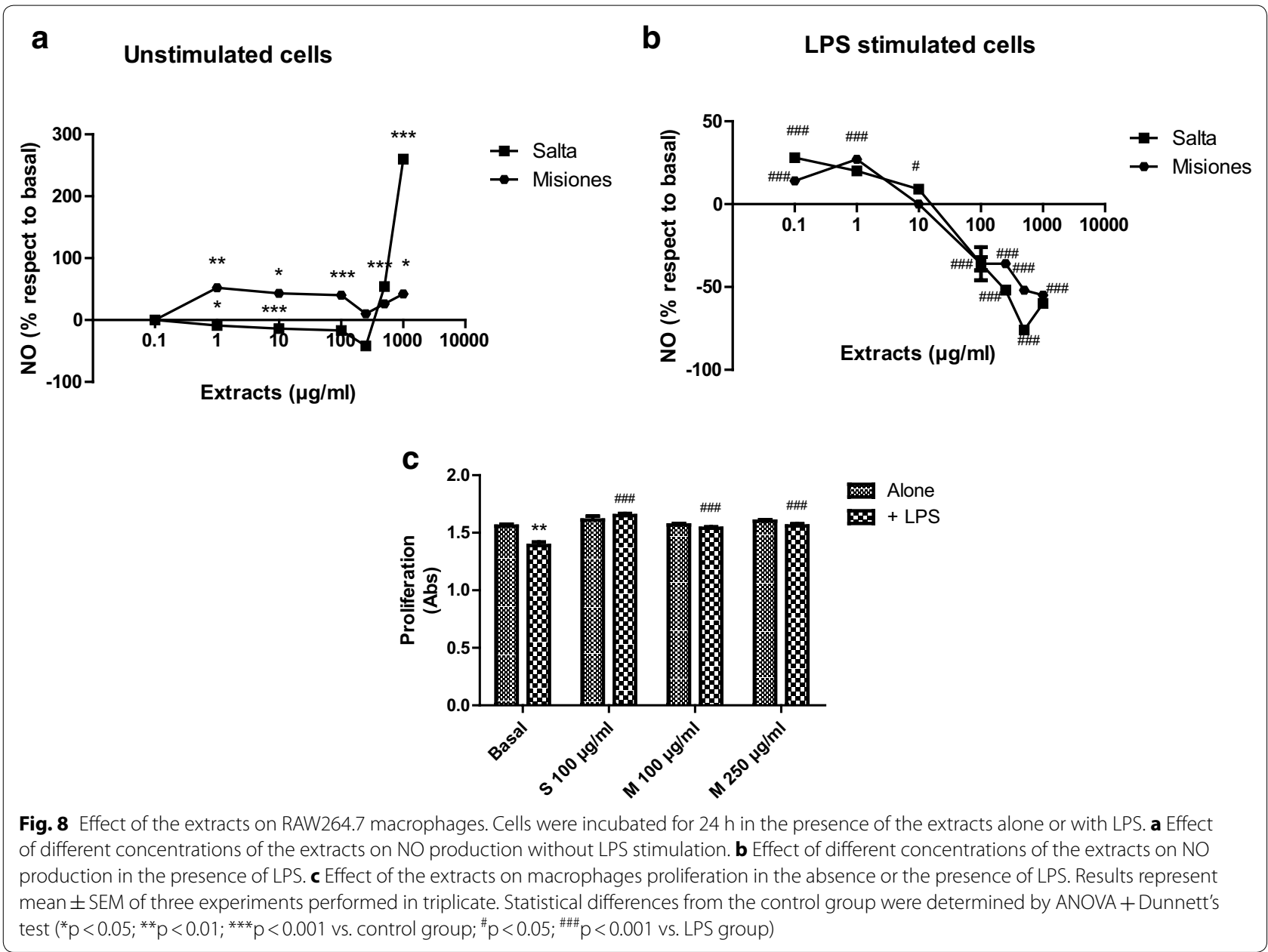

expected, the Salta extract exerted a higher antioxidant activity, as evidenced by the lower $\mathrm{EC}_{50}$ on both models. These effects were related to the polyphenol content, especially flavonoids. The $\mathrm{EC}_{50}$ of the extracts for the DPPH scavenger, reducing power and SOD like activities were lower or equal (depending on the extract) than the $\mathrm{EC}_{50}$ for lipid peroxidation, inhibition of albumin denaturation and protease inhibition. These results may suggest that an antioxidant activity is required to induce the anti-inflammatory actions.

Nitric oxide is a diffusible free radical that plays many roles as an effector molecule in diverse biological systems, including neuronal messenger, vasodilatation and antimicrobial and antitumor activities [33]. It is a potent pleiotropic inhibitor of physiological processes such as smooth muscle relaxation, neuronal signaling, inhibition of platelet aggregation, and regulation of cell mediated toxicity. It is known that NO induces cell death by apoptosis. Macrophages can produce high amounts of $\mathrm{NO}$ upon activation by cytokines and LPS. After stimulation with LPS, macrophages secrete several pro-inflammatory products such as TNF- $\alpha$, interleukins, and NO. Many transcriptor factor families, including NF-kB, activator protein 1 (AP-1), among others, are considered critical regulators of gene expression in the setting of the inflammatory process. Although these factors play an essential beneficial role in physiological processes, the deregulation of NF-kB activity and the sustained production of pro-inflammatory cytokines and $\mathrm{NO}$ are involved in the pathogenesis of several diseases [34].

In LPS-stimulated macrophages, both extracts were capable of decreasing the production of NO only at high concentrations, thus blunting the effect of LPS. Moreover, the extracts were able to revert the antiproliferative effect of LPS. All these effects suggested an antioxidant and anti-inflammatory activity at high concentrations. Low concentrations of the extracts had the opposite effect in NO production, increasing it without modification of cell proliferation. This protective effect of the extracts could be related to their antioxidant activity and to the presence of polyphenols. Many studies have shown that many flavonoids and related polyphenols contribute 


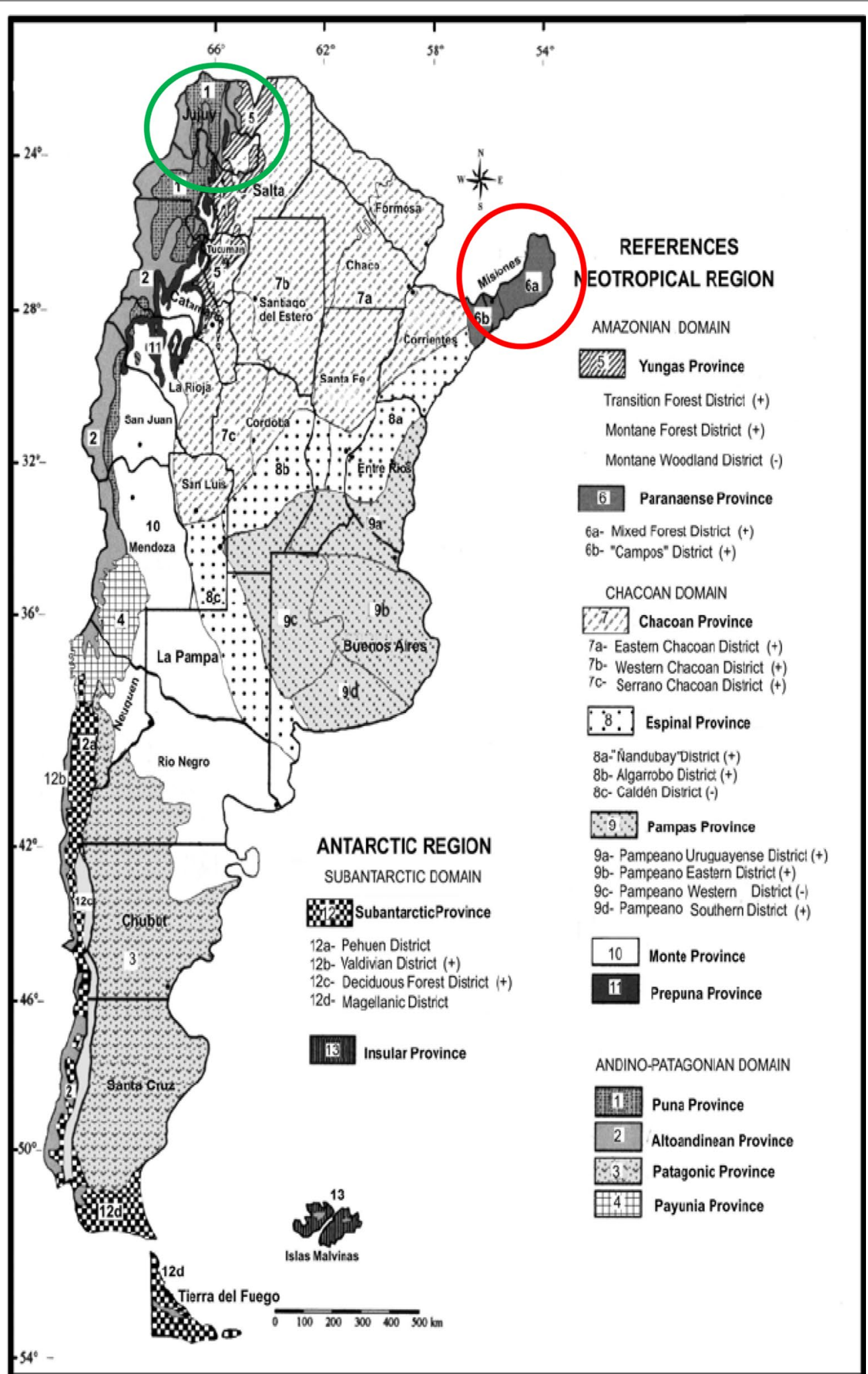

Fig. 9 Phytogeographic Argentinean provinces and Urera aurantiaca distribution. Paranaense phytogeographic Province and Yungas phytogeographic province are marked in red and green, respectively 
significantly to the anti-inflammatory activities exerted by many plants $[35,36]$.

In relation to NO production, it can be suggested that the extracts also exert an immunomodulatory activity on cells without LPS activation, demonstrating a prooxidant activity at low and high concentrations. The Salta extract appeared to be more effective in reducing the production of NO.

The differences observed in the antioxidant activities of the extracts could be related to a quantitative rather to a qualitative difference in the polyphenols content. These quantitative differences observed between both extracts could be a consequence of genotypic, developmental and environmental factors. It is known that specimens of same plant species growing under different environmental conditions show significant differences in the production and accumulation the primary and secondary metabolites [37]. Influenced by environmental factors, secondary metabolites act as a chemical interface between the plant and its environment. The chemical interaction between plants and their environment is mediated mainly by the biosynthesis of secondary metabolites, which exert their biological roles as a plastic adaptive response to their environment.

The Salta specimen was collected in the Oran zone (phytogeographic province of the Yungas) and the Misiones specimen was collected in Eldorado (Paranaense phytogeographic province) [38] (Fig. 9). These phytogeographic zones differ in climate, temperature and precipitations, factors which can influence the production of primary and secondary metabolites. In this sense, the Paranaense province is a moist forest with subtropical climate, whereas the Yungas is a rain mountain forest which constitutes a subtropical complex biome with extreme temperatures that range from $50{ }^{\circ} \mathrm{C}$ in summer to $10{ }^{\circ} \mathrm{C}$ in winter. The climate is wet and hot, with summer precipitations and winter frost. In fact, it is a very rainy and foggy zone. These differences between the biomes could explain the differences observed in the specimens.

\section{Conclusion}

The present study demonstrated the in vitro antioxidant and anti-inflammatory activities of two methanol extracts of $U$. aurantiaca. The presence of flavonoids and other polyphenols in the extracts may be responsible for the biological activity observed. The differences found between the extracts effectiveness are probably related to ambient conditions: temperature, rain, soil composition and ecosystem.

\section{Additional file}

Additional file 1. Minimum standards of reporting checklist.
Abbreviations

DPPH: 2,2-diphenyl-1-picrylhydrazyl; LPS: lipopolysaccharide; MTT:

3-(4,5-dimethylthiazol-2-yl)-2,5-diphenyltetrazolium bromide; NO: nitric oxide;

RNS: reactive nitrogen species; ROS: reactive oxygen species; SOD: superoxide dismutase.

\section{Authors' contributions}

CM and IP performed the experimental procedures. CA coordinated the work. All authors analysed the results. All authors read and approved the final manuscript.

\section{Acknowledgements \\ Not applicable.}

\section{Competing interests}

The authors declare that they have no competing interests.

\section{Availability of data and materials}

All data generated or analysed during this study are included in this published article.

\section{Consent for publication}

Not applicable.

Ethics approval and consent to participate

Not applicable.

Funding

This work was supported by Grant PIP 0007 from the National Research Council (CONICET).

\section{Publisher's Note}

Springer Nature remains neutral with regard to jurisdictional claims in published maps and institutional affiliations.

Received: 7 February 2018 Accepted: 12 April 2018

Published online: 19 April 2018

\section{References}

1. Kaplan M, Mutlu E, Benson M, Fields J, Banan A, Keshavarzian A. Use of herbal preparations in the treatment of oxidant mediated inflammatory disorders. Complement Ther Med. 2007;15:207-16.

2. Chatterjee S. Chapter two-oxidative stress, inflammation, and disease Oxidative stress and biomaterials. New York: Academic press Elsevier; 2016. p. 35-58.

3. Lee J, Koo N, Min DB. Reactive oxygen species, aging, and antioxidative nutraceuticals. Compr Rev Food Sci Food Saf. 2004;3:21-33.

4. Gou Z, Jiang S, Zheng C, Tian Z, Lin X. Equol inhibits LPS-induced oxidative stress and enhances the immune response in chicken HD11 macrophages. Cell Physiol Biochem. 2015;36:611-21.

5. Halliwell B. Free radicals and antioxidants: a personal review. Nutr Rev. 1994;52:253-65.

6. MartínezCrovetto R. Plantas utilizadas en medicina en el noroeste Corrientes. Corrientes: Miscelanea; 1981. p. 37.

7. Riedel R, Marrassini C, Anesini C, Gorzalczany S. Anti-inflammatory and antinociceptive activity of Urera aurantiaca. Phytother Res. 2015;2015(29):59-66.

8. Marrassini C, Anesini C. Modulatory effect of an Urera Aurantiaca extract on immune and tumoral cells during inflammation. Phytother Res. 2016;31:265-73.

9. Kasote DM, Jagtap SD, Thapa D, Khyade MS, Russell WR. Herbal remedies for urinary stones used in India and China: a review. J Ethnopharmacol. 2017:203:55-68.

10. Weckerle CS, Ineichen R, Huber FK, Yang Y. Mao's heritage: medicinal plant knowledge among the Bai in Shaxi, China, at a crossroads between 
distinct local and common widespread practice. J Ethnopharmacol. 2009;123:213-28.

11. Li DL, Xing FW. Ethnobotanical study on medicinal plants used by local Hoklos people on Hainan Island, China. J Ethnopharmacol. 2016;194:358-68.

12. Zheng $X L$, Wei JH, Sun W, Li RT, Liu SB, Dai HF. Ethnobotanical study on medicinal plants around Limu Mountains of Hainan Island, China. J Ethnopharmacol. 2013;148:964-74.

13. Au DT, Wu J, Jiang Z, Chen H, Lu G, Zhao Z. Ethnobotanical study of medicinal plants used by Hakka in Guangdong, China. J Ethnopharmacol. 2008;117:41-50.

14. Telascrea M, de Araujo CC, Marques MOM, Facanali R, de Moraes PLR, Cavalheiro AJ. Essential oil from leaves of Cryptocarya mandioccana Meisner (Lauraceae): composition and intraspecific chemical variability. Biochem Syst Ecol. 2007;35:222-32.

15. Rahimmalek M, Tabatabaei BES, Etemadi N, Goli SAH, Arzani A, Zeinali H. Essential oil variation among and within six Achillea species transferred from different ecological regions in Iran to the field conditions. Ind Crops Prod. 2009;29:348-55.

16. Singleton VL, Orthofer R, Lamuela-Raventós RM. Analysis of total phenols and other oxidation substrates and antioxidants by means of Folin-Ciocalteu reagent. Methods Enzymol. 1999;299:152-78.

17. Chang CC, Yang MH, Wen HM, Chern JC. Estimation of total flavonoid content in propolis by two complementary colorimetric methods. J Food Drug Anal. 2002;10:178-82.

18. Santos SC, Mello JCP. Farmacognosia da planta ao medicamento. 5th ed. Porto Alegre: Editora da URFGS/UFSC; 2004. p. 615-56.

19. Amorim ELC, Nascimento JE, Monteiro JM, Peixoto Sobrinho TJS, Araujo TAS, Albuquerque UP. A simple and accurate procedure for the determination of tannin and flavonoid levels and some applications in ethnobotany and ethnopharmacology. Functional ecosystems and communities. Funct Ecosyst Commun. 2008;2:88-94.

20. Filip R, Lopez P, Giberti G, Coussio J, Ferraro G. Fitoterapia. 2001:72:774-8.

21. Becherel PA, Chosidow O, LeGoff L, Frances C, Debre P, Mossalayi MD. Inducible nitric oxide synthase and proinflammatory cytokine expression by human keratinocytes during acute urticaria. Mol Med. 1997;3:686-94.

22. Blois MS. Antioxidant determination by the use of a stable free radical. Nat Geosci. 1958;181:1199-200.

23. Carrillo MC, Kanai S, Nokubo M, Kitani K. Der-prenyl induces activities of both superoxide dismutase and catalase but not glutathione peroxidase in the striatum of young male rats. Life Sci J. 1991;48:517-21.

24. Ferreira ICFR, Baptista P, Vilas-Boas M, Barros L. Free radical scavenging capacity and reducing power of wild edible mushroom from northeast Portugal: individual cap and stipe activity. Food Chem. 2007;100:1511-6.
25. Dissanayake DP, Abeytunga D, Vasudewa NS, Ratnasooriya WD. Inhibition of lipid peroxidation by extracts of Pleurotus ostreatus. Phcog Mag. 2009:5:266-71.

26. Kumari CS, Yasmin N, Hussain MR, Babuselvam M. In vitro anti-inflammatory and anti-arthritic property of Rhizopora mucronata leaves. Int J Pharm Sci Res. 2015;6:482-5.

27. Sakat SS, Juvekar AR, Gambhire MN. In vitro antioxidant and anti-inflammatory activity if methanol extract of Oxalis corniculata Linn. Int J Pharm Pharm Sci. 2010;2:146-55.

28. Oyedapo OO, Famurewa AJ. Antiprotease and membrane stabilizing activities of extracts of Fagara zanthoxyloides, Olax subscorpioides and Tetrapleura tetraptera. Int J Pharmacogn. 1995;33:65-9.

29. Yen GC, Chen HY. Antioxidant activity of various tea extracts in relation to their antimutagenicity. J Agric Food Chem. 1995;43:27-32.

30. Brand-Williams W, Cuvelier ME, Berset C. Use of a free radical method to evaluate antioxidant activity. Lebenson Wiss Technol. 1995;28:25-30.

31. Kondo K, Kurihara M, Fukuhara K, Tanaka T, Suzuki T, Miyata N, Toyoda M. Conversion of procyanidin B-type (catechin dimer) to A-type: evidence for abstraction of $\mathrm{C}-2$ hydrogen in catechin during radical oxidation. Tetrahedron Lett. 2000;41:485-8.

32. Alam MB, Hossain MS, Haque ME. Antioxidant and anti-inflammatory activities of the leaf extract of Brassica nigra. IJPSR. 2015:2:303-10.

33. Hagerman AE, Riedl KM, Jones GA, Sovik KN, Ritchard NT, Hartzfeld PW. High molecular weight plant polyphenolics (tannins) as biological antioxidants. J Agric Food Chem. 1998;46:1887-92.

34. Marrassini C, Davicino R, Acevedo C, Anesini C, Gorzalczany S, Ferraro G. Vicenin-2, a potential anti-inflammatory constituent of Urtica circularis. J Nat Prod. 2011;74:1503-7.

35. Luo XD, Basile MJ, Kennelly EJ. Polyphenolic antioxidants from the fruits of Chrysophyllum cainito L. (star apple). J Agric Food Chem. 2002;50:1379-82.

36. Okoli CO, Akah PA. Mechanism of the antiinflammatory activity of the leaf extracts of Culcasia scandens P. beauv (Araceae). Pharmacol Biochem Behav. 2004;79:473-81.

37. Sampaio BL, Edrada-Ebel R, Da Costa FB. Effect of the environment on the secondary metabolic profile of Tithonia diversifolia: a model for environmental metabolomics of plants. Sci Rep. 2016;6:1-11.

38. Cabrera AL. Regiones fitogeográficas argentinas. Enciclopedia argentina de agricultura y jardinería. Buenos Aires: Acme; 1976. p. 85.

Ready to submit your research? Choose BMC and benefit from

- fast, convenient online submission

- thorough peer review by experienced researchers in your field

- rapid publication on acceptance

- support for research data, including large and complex data types

- gold Open Access which fosters wider collaboration and increased citations

- maximum visibility for your research: over $100 \mathrm{M}$ website views per year

At BMC, research is always in progress.

Learn more biomedcentral.com/submissions 